and long-term (24 months) served as primary outcomes measure, function as secondary. Outcome measures measured on different scales were standardized to a $0-100$ scale to pool the data. All analyses were performed with and without stratifying for affected joint and type of glucosamine substance.

Results: Out of 21 eligible studies, six studies $(\mathrm{N}=1663)$ shared their trial data with the OA Trial Bank. Only one of these studies $(\mathrm{N}=40)$ was industry driven. All six studies had a low risk of bias, of which five trials (all not industry driven) compared glucosamine to placebo. These five studies represented $50 \%$ of the total number of randomized subjects in all published trials for this comparison. No main effects of glucosamine were found on pain or function at short-term (mean difference $0.3195 \% \mathrm{Cl}$ [-2.02 to 2.64$]$ and 1.56 [-0.56 to 3.69], respectively) and at long-term follow-up (0.98 [-1.76 to 3.73$]$ and 1.40 [-1.27 to 4.06$]$, respectively). Also, no significant interactions with treatment were found for subgroups based on pain severity (WOMAC pain $<70 \mathrm{vs.} \geq 70$ ), BMI $\left(<27 \mathrm{~kg} / \mathrm{m}^{2} \mathrm{vs} . \geq 27 \mathrm{~kg} / \mathrm{m}^{2}\right)$, sex (male vs. female) and structural abnormalities (KL-grade $0-2$ vs. 3-4), see Table. Stratification for knee OA patients only and for type of glucosamine did not result in any differences in the outcomes. No data was available to adequately form subgroups based on degree of inflammation.

\begin{tabular}{|c|c|c|c|c|c|c|}
\hline & & $\begin{array}{l}\text { All studies } \\
(\mathrm{N}=1394)\end{array}$ & $\begin{array}{c}\text { Knee } O A \\
\text { only } \\
(\mathrm{N}=1172)\end{array}$ & $\begin{array}{l}\text { GH in knee } O A \\
\quad(N=671)\end{array}$ & $\begin{array}{l}\text { GS in knee } \\
\text { and hip OA } \\
(N=723)\end{array}$ & $\begin{array}{c}\text { GS in knee } O A \\
\quad(N=501)\end{array}$ \\
\hline \multirow{7}{*}{ 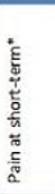 } & \multicolumn{6}{|c|}{ Estimated pooled differences and $95 \%$ confidence interval } \\
\hline & $\begin{array}{l}\text { Glucosamine vs } \\
\text { placebo }\end{array}$ & $\begin{array}{c}0.31 \\
(-2.02-2.64)\end{array}$ & $\begin{array}{c}0.53 \\
(-2.21-3.26)\end{array}$ & $\begin{array}{c}1.97 \\
(-1.14-5.09)\end{array}$ & $\begin{array}{c}-2.62 \\
(-6.03-0.79)\end{array}$ & $\begin{array}{c}-5.99 \\
(-11.50--0.48)\end{array}$ \\
\hline & \multicolumn{6}{|c|}{$p$-values for treatment-subgroup interactions } \\
\hline & Pain subgroup & 0.80 & 0.92 & 0.94 & 0.59 & 0.81 \\
\hline & BMI subgroup & 0.36 & 0.66 & 0.83 & 0.30 & 0.43 \\
\hline & Sex subgroup & 0.80 & 0.70 & 0.80 & 0.67 & 0.62 \\
\hline & KL subgroup & - & - & - & $\cdot$ & - \\
\hline \multirow{7}{*}{ 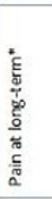 } & \multicolumn{6}{|c|}{ Estimated pooled differences and $95 \%$ confidence interval } \\
\hline & $\begin{array}{l}\text { Glucosamine vs } \\
\text { placebo }\end{array}$ & $\begin{array}{c}0.98 \\
(-1.76-3.73)\end{array}$ & $\begin{array}{c}0.19 \\
(-2.83-3.22)\end{array}$ & $\begin{array}{c}0.78 \\
(-4.33-5.89)\end{array}$ & $\begin{array}{c}1.22 \\
(-1.90-4.33)\end{array}$ & $\begin{array}{c}-0.38 \\
(-3.67-2.90)\end{array}$ \\
\hline & \multicolumn{6}{|c|}{$\rho$-values for treatment-subgroup interactions } \\
\hline & Pain subgroup & 0.26 & 0.28 & 0.42 & 0.44 & 0.86 \\
\hline & BMI subgroup & 0.55 & 0.10 & 0.51 & 0.72 & 0.10 \\
\hline & Sex subgroup & 0.46 & 0.53 & 0.75 & 0.52 & 0.77 \\
\hline & KL subgroup & $\cdot$ & 0.40 & 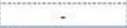 & $\cdot$ & $\cdot$ \\
\hline \multirow{7}{*}{ 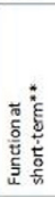 } & \multicolumn{6}{|c|}{ Estimated pooled differences and $95 \%$ confidence interval } \\
\hline & $\begin{array}{l}\text { Glucosamine vs } \\
\text { placebo }\end{array}$ & $\begin{array}{c}1.56 \\
(-0.56-3.69)\end{array}$ & $\begin{array}{c}1.57 \\
(-0.93-4.31)\end{array}$ & $\begin{array}{c}2.13 \\
(-0.82-5.09)\end{array}$ & $\begin{array}{c}0.74 \\
(-2.06-3.53)\end{array}$ & $\begin{array}{c}-1.38 \\
(-5.91-3.16)\end{array}$ \\
\hline & \multicolumn{6}{|c|}{$\rho$-values for treatment-subgroup interactions } \\
\hline & Pain subgroup & 0.46 & 0.32 & 0.38 & 0.97 & 0.90 \\
\hline & BMI subgroup & 0.92 & 0.87 & 1.00 & 0.83 & 0.45 \\
\hline & Sex subgroup & 0.55 & 0.37 & 0.23 & 0.49 & 0.79 \\
\hline & KL subgroup & $\cdot \cdot$ & $\cdot$ & $\cdot$ & $\cdot$ & $\cdot$ \\
\hline \multirow{7}{*}{ 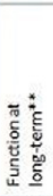 } & \multicolumn{6}{|c|}{ Estimated pooled differences and $95 \%$ confidence interval } \\
\hline & $\begin{array}{l}\text { Glucosamine vs } \\
\text { placebo }\end{array}$ & $\begin{array}{c}1.40 \\
(-1.27-4.06)\end{array}$ & $\begin{array}{c}0.63 \\
(-2.31-3.58)\end{array}$ & $\begin{array}{c}0.85 \\
(-4.43-6.13)\end{array}$ & $\begin{array}{c}2.02 \\
(-0.82-4.86)\end{array}$ & $\begin{array}{c}0.62 \\
(-2.29-3.52)\end{array}$ \\
\hline & \multicolumn{6}{|c|}{$p$-values for treatment-subgroup interactions } \\
\hline & Pain subgroup & 0.49 & 0.38 & 0.55 & 0.94 & 0.91 \\
\hline & BMI subgroup & 0.82 & 0.42 & 0.65 & 0.56 & 0.68 \\
\hline & Sex subgroup & 0.72 & 0.61 & 0.80 & 1.00 & 0.94 \\
\hline & KL subgroup & $\cdot$ & 0.77 & $\cdot$ & $\cdot$ & $\cdot$ \\
\hline \multicolumn{7}{|c|}{$\begin{array}{l}\text { "measured using WOMAC pain }(0-100) \text { and adjusted for age sex, BMI, wOMAC pain at baseline and } \\
\text { study number. }{ }^{* x} \text { measured using WOMAC function }(0-100) \text { and adjusted for age sex, BMI, WOMAC } \\
\text { function at baseline and study number. Positive estimated pooled differences indicate a greater } \\
\text { reduction in the outcome in the glucosamine group compared to the placebo group. } G S=\text { glucosamine } \\
\text { sulphate; } G H=\text { glucosamine hydrochloride. }\end{array}$} \\
\hline
\end{tabular}

Conclusions: The majority of industry-led glucosamine studies for osteoarthritis did not wish to share data, challenging optimal use of available data. There is currently no evidence for the use of glucosamine for the treatment of hip or knee osteoarthritis and an absence of support for clinically relevant subgroups of $\mathrm{OA}$ patients according to baseline pain severity, BMI, sex, and structural abnormalities.

Disclosure of Interest: None declared

DOI: 10.1136/annrheumdis-2017-eular.5986

\section{SAT0524 UTILITY OF TOCILIZUMAB IN CLINICAL MANIFESTATIONS OF EROSIVE OSTEOARTHROSIS OF HANDS REGIONAL HOSPITAL ISSSTE PUEBLA, MÉXICO}

J.M. Sánchez Huerta ${ }^{1}$, J. Gálvez-Romero ${ }^{2}$, W. López-Rodriguez ${ }^{1}$, A. López ${ }^{3}$. ${ }^{1}$ Rheumatology; ${ }^{2}$ ISSSTE, Puebla, Puebla; ${ }^{3}$ UDLAP, Cholula, Puebla, Mexico

Background: Erosive osteoarthritis (EOA) is a form of severe involvement of osteoarthrosis in the hands, characterized by inflammation of the synovium of the proximal interphalangeal (PIF) and distal joints (DIF); the last ones are the most affected in a symmetrical manner. Inhibition of interleukin 6 (IL-6) in joints with osteoarthrosis helps to improve the production of the cartilaginous matrix and microfractures of articular cartilage.

Objectives: To know if the application of TCZ is useful for the control of the clinical manifestations of EOA of the hands.

Methods: Twenty-four patients with EOA were studied, 18 females and 6 males with ages ranging from 42 to 72 years, with an evolution time of 4 to 30 years. The application of TCZ was intravenous ( $8 \mathrm{mg} / \mathrm{kg}$ of body weight per month). Articular pain in the PIF and distal joints was evaluated by the visual analogue scale (VAS) (0 to 10) and joint pain (0 to 50 ), morning stiffness (0 to 10), and functional limitation (0-90) by the AUSCAN index.

Results: The VAS showed improvement of $30 \%$ ( $0 \%$ to $100 \%$ ). The AUSCAN index showed improved pain (16.2), morning stiffness (0.6) and functional limitation (17.5). Decreased ESR, CRP, and IL-6 levels less than 1.56 to 59.1 $\mathrm{pg} / \mathrm{ml}$.

Conclusions: IV Tocilizumab is useful for the control of the clinical manifestations of OAE of the hands. More precise studies are needed to evaluate the improvement of the cartilaginous matrix in EOA by TCZ.

Disclosure of Interest: None declared

DOI: 10.1136/annrheumdis-2017-eular.6483

\section{SAT0525 THE EFFICACY OF PELOID THERAPY IN MANAGEMENT OF HAND OSTEOARTHRITIS}

M. Aksoy Kasapoğlu ${ }^{1}$, L. Altan ${ }^{2}$, R. Eröksüz ${ }^{3}$, B. ÖkmenMetin ${ }^{1} .{ }^{1}$ Physical Medicine and Rehabilitation, University of Health Sciences Bursa Yüksek Ihtisas Training and Research Hospital; ${ }^{2}$ Physical Medicine and Rehabilitation, Uludağ University Medical Faculty; ${ }^{3}$ Ecology and Hydroclimatology, University of Health Sciences Bursa Yüksek Ihtisas Training and Research Hospital, Bursa, Turkey

Background: Hand osteoarthritis $(\mathrm{OA})$ is associated with pain, reduced grip strength, loss of range of motion (ROM), and joint stiffness, leading to impaired hand function and difficulty in performance of daily living activities. Various randomized controlled clinical trials were conducted to assess the efficacy and tolerability of mud-pack therapy in patients with knee OA. Data from these clinical trials support the beneficial effect of mud-pack therapy on pain, function, and quality of life in knee OA. However, to the best of our knowledge, in spite of its significant impact of on the activities of daily life, there is a lack of adequate randomized controlled studies on peloid therapy in management of osteoarthritis of the hand

Objectives: To investigate the effects of peloid therapy in the patients with hand $O A$ on pain, functional state, grip strength, and the quality of life

Methods: 63 patients aged between 35 and 75 years, who had been diagnosed with hand OA were included in the study. Patients were randomized into 2 groups with a random number table. Patients in Group $1(n=33)$ underwent peloid therapy over 2 weeks, 5 sessions a week, for a total of 10 sessions and home exercise program. Patients in Group 2 (control, $n=30$ ) received only the same home exercise program as in Group 1. Patients were evaluated just before, and 2 and 6 weeks after the start of the study with Visual Analogue Scale (VAS), Australian/Canadian Osteoarthritis Hand Index (AUSCAN) Health Assessment Questionnaire (HAQ), Hand Grip Strength (HGS), Pinch strength (PS).

Results: Statistically significant improvements were observed in all parameters assessed at week 2 and week 6 in the Group $1(p<0.05)$. Statistically significant differences were observed in HGS scores in the Group 2 at week 2, and in AUSCAN scores at week $6(p<0.05)$. Intergroup comparisons of the scores revealed significant differences between the peloid therapy group and control group in VAS, HAQ, AUSCAN, HGS and PS scores at week 2 and week 6 $(p<0,05)$.

Conclusions: This study demonstrates that peloid therapy is an effective and confident treatment modality in the management of symptomatic osteoarthritis of the hand and provides effective pain control and improvements in the hand functions, quality of life and grip strength

\section{References:}

[1] Zhang Y, Niu J, Kelly-Hayes M, Chaisson CE, Aliabadi P, Felson DT. Prevalence of symptomatic hand osteoarthritis and its impact on functional status among the elderly. Am J Epidemiol 2002;156:1021-7.

[2] Bellometti S, Cecchettin M, Galzigna L (1997) Mud-pack therapy in osteoarthrosis. Changes in serum levels of chondrocyte markers. Clin Chim Acta 268:101-106.

[3] Odabaș E, Turan M, Erdem H, Pay S, Gülec M, Karagülle MZ. The Effect of Mud Pack Treatment in Knee Osteoarthritis. Turk J Rheumatol 2009; 24: 72-6. Disclosure of Interest: None declared

DOI: 10.1136/annrheumdis-2017-eular.2310

\section{SAT0526 POSSIBILITY OF CARTILAGE REPAIR WITH PLATELET AUTOLOGOUS PLASMA (PAP)}

L.V. Khimion ${ }^{1}$, O.A. Burianov ${ }^{2}$, L.O. Smolina ${ }^{1}$, H. Havryliuk ${ }^{1}$, T. Omelchenko ${ }^{3}$. ${ }^{1}$ Department of Family Medicine, Shupyk National Medical Academy of

Postgraduate Education; ${ }^{2}$ Traumatology and Orthopedic Department;

${ }^{3}$ Traumatology and Orthopedic Department, Bogomolets National Medical University, Kiyv, Ukraine

Background: The investigations of the platelet-derived biologic agents in osteoarthritis treatment had shown promising but often controversial results.

Objectives: To study the efficacy (in clinic \& experiment) \& safety (in clinic) of the platelet autologous plasma (PAP) in cartilage repair and treatment of early knee OA.

Methods: The study was conducted at the Department of Family Medicine and Traumatology and Orthopedic Department and consisted of 2 parts: experimental (20 rabbits with the traumatic damage of the knee cartilages) and clinical (included 146 patients with diagnosed knee OA (radiological stage I-II). Rabbits 